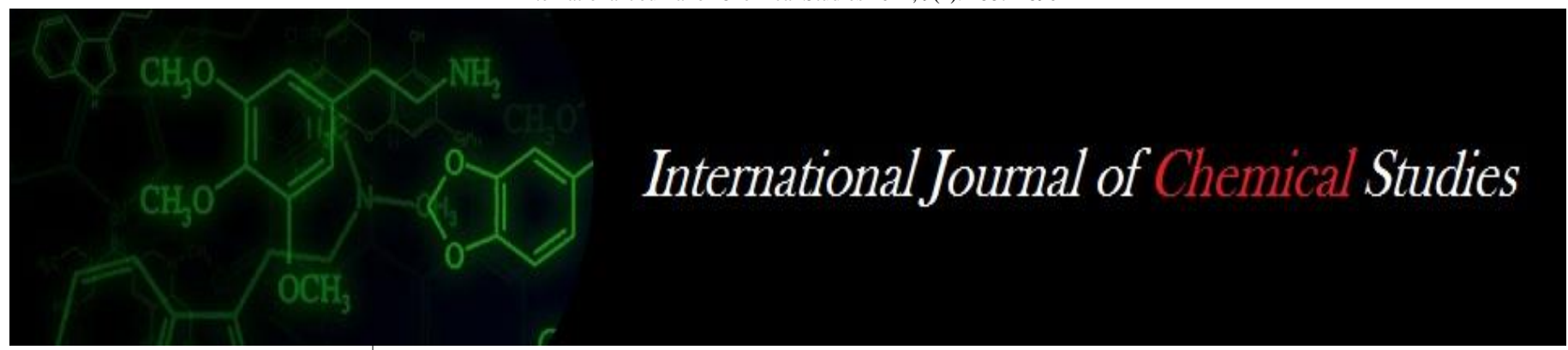

P-ISSN: 2349-8528

E-ISSN: 2321-4902

www.chemijournal.com

IJCS 2021; 9(1): 1887-1890

(C) 2021 IJCS

Received: 02-10-2020

Accepted: 09-11-2020

Shivani Regulwar

AICRP for Dryland Agriculture,

Dr. Panjabrao Deshmukh Krishi

Vidyapeeth, Akola,

Maharashtra, India

VV Gabhane

AICRP for Dryland Agriculture,

Dr. Panjabrao Deshmukh Krishi

Vidyapeeth, Akola,

Maharashtra, India

\section{Anant Fulzele}

AICRP for Dryland Agriculture, Dr. Panjabrao Deshmukh Krishi

Vidyapeeth, Akola,

Maharashtra, India

\section{Jaipal Yadav}

AICRP for Dryland Agriculture, Dr. Panjabrao Deshmukh Krishi Vidyapeeth, Akola,

Maharashtra, India

\section{RS Patode}

AICRP for Dryland Agriculture, Dr. Panjabrao Deshmukh Krishi Vidyapeeth, Akola,

Maharashtra, India

\section{BA Sonune}

AICRP for Dryland Agriculture, Dr. Panjabrao Deshmukh Krishi Vidyapeeth, Akola,

Maharashtra, India
Corresponding Author: Shivani Regulwar AICRP for Dryland Agriculture, Dr. Panjabrao Deshmukh Krishi Vidyapeeth, Akola, Maharashtra, India

\section{Long term effect of integrated nutrient management on soil fertility and nutrient balance in cotton + greengram (1:1) intercropping system on Vertisols}

\author{
Shivani Regulwar, VV Gabhane, Anant Fulzele, Jaipal Yadav, RS Patode \\ and BA Sonune
}

DOI: https://doi.org/10.22271/chemi.2021.v9.i1aa.11497

\begin{abstract}
A field study was conducted during kharif 2019-20 at Research field of AICRP for Dryland Agriculture, Dr. Panjabrao Deshmukh Krishi Vidyapeeth, Akola, Maharashtra to assess the long term effect of integrated nutrient management on soil fertility and yield of cotton+greengram intercropping system in Vertisols. The soil of the experimental site was Vertisol which was moderately alkaline in reaction, low in available nitrogen, medium in available phosphorus and high in available potassium. The eight treatments replicated three times in randomized block design comprised of control, 50\% and 100\% RDF, $50 \% \mathrm{~N} \mathrm{ha}^{-1}$ through gliricidia/FYM, 50\% $\mathrm{N}$ fertilizers $+50 \% \mathrm{~N} \mathrm{ha}^{-1}$ through gliricidia / FYM $+100 \%$ $\mathrm{P}_{2} \mathrm{O}_{5}+100 \% \mathrm{~K}_{2} \mathrm{O}$ ha $^{-1}$ fertilizers, $100 \% \mathrm{~N} \mathrm{ha}^{-1}$ through gliricidia $+100 \% \mathrm{P}_{2} \mathrm{O}_{5}+100 \% \mathrm{~K}_{2} \mathrm{O}$ ha $^{-1}$ fertilizers. The significant improvement in soil fertility with higher nutrient balance was recorded with application of $50 \% \mathrm{~N}$ through gliricidia $+50 \% \mathrm{~N}+100 \% \mathrm{P}_{2} \mathrm{O}_{5}+100 \% \mathrm{~K}_{2} \mathrm{O}$ ha $^{-1}$ through fertilizers and was on par with $50 \%$ RDN through FYM in combination with $50 \% \mathrm{~N}+100 \% \mathrm{P}_{2} \mathrm{O}_{5}+100 \% \mathrm{~K}_{2} \mathrm{O}^{-1}$ through fertilizers in Vertisols under cotton+greengram(1:1) intercropping system.
\end{abstract}

Keywords: Integrated nutrient management, soil fertility and vertisols

\section{Introduction}

Cotton is a soft, fluffy staple fiber that grows in a boll, or protective case, around the seeds of the cotton plants of the genus Gossypium in the mallow family Malvaceae. The fiber is almost pure cellulose. Among different species of cotton Gossypium hirsutum and Gossypium arboreum are commonly grown in Maharashtra and used in textile industries for manufacture of cloth. India is the largest cotton growing country in the world and occupies $37.5 \%$ world cotton area and produces around $24.3 \%$ of world cotton production. In 2019-20 area, production and productivity under cotton in India is estimated as 125.84 lakh ha, 360.0 lakh bales of $170 \mathrm{~kg}$ and $486 \mathrm{~kg} \mathrm{ha}^{-1}$ respectively. In India, Maharashtra rank first in acreages with 43.69 lakh ha and 82.0 lakh bales production with average productivity of $319 \mathrm{~kg}$ lint/ha (Anonymous, 2020a) ${ }^{[1]}$. In Maharashtra state, Vidarbha is the largest cotton growing region accounting for 15.81 lakh ha ${ }^{-1}$ acreage with production of 35.5 lakh bales and productivity of $388.0 \mathrm{~kg}$ lint ha ${ }^{-1}$ (Anonymous, 2020b) ${ }^{[2]}$.

Greengram also known as 'moong' is one of the main pulse crop of India. It is a rich source of protein along with fibre and iron. It can be cultivated as kharif as well as summer crop. Greengram is also known as "golden gram" and it contains $20-25 \%$ protein, $1.3 \%$ fat, $3.5 \%$ minerals, $4.1 \%$ fiber and $56.7 \%$ carbohydrates. In India, the area under greengram is about 34.4 lakh ha with production of 14.00 lakh tonnes and productivity of $406.98 \mathrm{~kg} \mathrm{ha}^{-1}$ whereas; Maharashtra has about 4.8 lakh ha area with production of 2.0 lakh tonnes and productivity of $423.6 \mathrm{~kg} \mathrm{ha}^{-1}$. The area under greengram in Vidarbha is 0.83 lakh ha and production of 0.44 lakh tones with productivity of $333.0 \mathrm{~kg} \mathrm{ha}^{-1}$ (Anonymous, 2020b) ${ }^{[2]}$.

Integrated nutrient management is the process to maintain the soil fertility and plant nutrient supply at an optimum level through optimization by the benefits of all possible sources of nutrients like inorganic, organic, bio-fertilizers and through green manure. It enhances the availability of applied as well as native soil nutrients, synchronizes the nutrient demand of the 
crop with nutrient supply from native and applied sources and improves the physical, chemical and biological functioning of soil. There is now tremendous pressure on growers to use integrated nutrient management approach to increase productivity and sustain soil health. Organic amendment offers an alternative or supplementing control tactic to increase production (Meena et al., 2015) ${ }^{[6]}$.

\section{Materials and Methods}

With the aim of maintenance of soil fertility and nutrient balance through optimization of benefit from organic plant nutrient sources available at farm level in the region, a fixed frame plot experiment with the combinations of organic and inorganic nutrient sources is being conducted in cotton+greengram intercropping system on Vertisols since 1987-88. The present study was carried out during 2019-20
( $33^{\text {rd }}$ cycle). The eight treatments replicated three times in randomized block design comprised of control, 50\% and $100 \% \mathrm{RDF}, 50 \% \mathrm{~N} \mathrm{ha}{ }^{-1}$ through gliricidia/FYM, 50\% $\mathrm{N}$ fertilizers $+50 \% \mathrm{~N} \mathrm{ha}^{-1}$ gliricidia/FYM $+100 \% \mathrm{P}_{2} \mathrm{O}_{5}+100 \%$ $\mathrm{K}_{2} \mathrm{O}$ ha $^{-1}$ fertilizers and $100 \% \mathrm{~N} \mathrm{ha}^{-1}$ gliricidia $+100 \% \mathrm{P}_{2} \mathrm{O}_{5}+$ $100 \% \mathrm{~K}_{2} \mathrm{O}$ ha $^{-1}$ fertilizers. The plotwise surface soil samples were collected and analysed for available nutrients as per standard methods.

\section{Results and Discussion Organic carbon}

The experimental results presented in Table 1 indicates that, there was a build up of organic carbon status of soil under cotton + greengram intercropping system in all treatments excluding control over the initial status $(0.46 \%)$.

Table 1: Effect of long term INM treatments on organic carbon in soil

\begin{tabular}{|c|c|c|c|}
\hline \multicolumn{2}{|r|}{ Treatments } & $\mathrm{OC}(\%)$ & OC balance (\%) \\
\hline $\mathrm{T}_{1}$ & Control & 0.45 & -0.01 \\
\hline $\mathrm{T}_{2}$ & $100 \%$ RDF & 0.61 & 0.15 \\
\hline $\mathrm{T}_{3}$ & $50 \% \mathrm{RDF}$ & 0.53 & 0.07 \\
\hline $\mathrm{T}_{4}$ & $50 \% \mathrm{~N} \mathrm{ha}^{-1}$ gliricidia & 0.60 & 0.14 \\
\hline $\mathrm{T}_{5}$ & $50 \% \mathrm{~N} \mathrm{ha}^{-1} \mathrm{FYM}$ & 0.61 & 0.15 \\
\hline $\mathrm{T}_{6}$ & $50 \% \mathrm{~N}$ fertilizers $+50 \% \mathrm{~N}^{-1}$ gliricidia $+100 \% \mathrm{P}_{2} \mathrm{O}_{5}+100 \% \mathrm{~K}_{2} \mathrm{O}$ ha $^{-1}$ fertilizers & 0.73 & 0.27 \\
\hline $\mathrm{T}_{7}$ & $50 \% \mathrm{~N}$ fertilizers $+50 \% \mathrm{~N} \mathrm{ha}^{-1} \mathrm{FYM}+100 \% \mathrm{P}_{2} \mathrm{O}_{5}+100 \% \mathrm{~K}_{2} \mathrm{O} \mathrm{ha}^{-1}$ fertilizers & 0.72 & 0.26 \\
\hline $\mathrm{T}_{8}$ & $100 \% \mathrm{~N} \mathrm{ha}^{-1}$ gliricidia $+100 \% \mathrm{P}_{2} \mathrm{O}_{5}+100 \% \mathrm{~K}_{2} \mathrm{O} a^{-1}$ fertilizers & 0.69 & 0.23 \\
\hline \multicolumn{2}{|r|}{ SE $(\mathrm{m}) \pm$} & 0.02 & - \\
\hline \multicolumn{2}{|r|}{$\mathrm{CD}$ at $5 \%$} & 0.07 & - \\
\hline
\end{tabular}

The treatments which received organic matter through FYM and green leaf manuring of gliricidia lopping recorded improvement in the organic carbon content of the soil over control. However, highest $0.73 \%$ soil organic carbon was recorded in treatment $50 \% \mathrm{~N} \mathrm{ha}^{-1}$ gliricidia $+50 \% \mathrm{~N}+100 \%$ $\mathrm{P}_{2} \mathrm{O}_{5}+100 \% \mathrm{~K}_{2} \mathrm{O}$ ha $^{-1}$ fertilizers $\left(\mathrm{T}_{6}\right)$ followed by $0.72 \%$ organic carbon content in $50 \% \mathrm{~N} \mathrm{ha}^{-1} \mathrm{FYM}+50 \% \mathrm{~N}+100 \%$ $\mathrm{P}_{2} \mathrm{O}_{5}+100 \% \mathrm{~K}_{2} \mathrm{O}$ ha $^{-1}$ fertilizers $\left(\mathrm{T}_{7}\right)$ and $100 \% \mathrm{~N} \mathrm{ha}^{-1}$ gliricidia $+100 \% \mathrm{P}_{2} \mathrm{O}_{5}+100 \% \mathrm{~K}_{2} \mathrm{O}$ ha $^{-1}$ fertilizers $\left(\mathrm{T}_{8}\right)$ which were found to be on par with each other. The lower value $(0.45 \%)$ of organic carbon was found in treatment $\mathrm{T}_{1}$ i.e. control.

The higher values of organic carbon content with application of gliricidia and FYM green leaf manuring may be attributed to addition of organic materials and greater root biomass with their addition as evidenced from the higher yields obtained in these treatments. Application of organic sources and/ or combination with chemical fertilizer helped for building up of organic carbon. Similar results were also reported by Regar et al. (2009) [9], Sharma et al. (2011) ${ }^{[11]}$ and Tamboli et al. $(2013)^{[13]}$.

\section{Organic carbon balance}

The data in respect of organic carbon balance (Table 1) indicates the higher gain of $0.27 \%$ in treatment $50 \% \mathrm{~N} \mathrm{ha}^{-1}$ gliricidia $+50 \%+100 \% \mathrm{P}_{2} \mathrm{O}_{5}+100 \% \mathrm{~K}_{2} \mathrm{O}$ ha $^{-1}$ fertilizers ( $\left.\mathrm{T}_{6}\right)$ followed by treatments $50 \% \mathrm{~N} \mathrm{ha}^{-1} \mathrm{FYM}+50 \% \mathrm{~N}+$ $100 \% \mathrm{P}_{2} \mathrm{O}_{5}+100 \% \mathrm{~K}_{2} \mathrm{O}^{-1}$ fertilizers $\left(\mathrm{T}_{7}\right)$ and $100 \% \mathrm{~N} \mathrm{ha}^{-1}$ gliricidia $+100 \% \mathrm{P}_{2} \mathrm{O}_{5}+100 \% \mathrm{~K}_{2} \mathrm{O}^{-1}$ fertilizers $\left(\mathrm{T}_{8}\right)$.

Soil, water and temperature are the limiting factors of the dryland agriculture and have direct influence on the soil organic carbon. Natural incorporation of the crop residues in to the soil after harvest of the crop is common phenomenon, but year after year, continuous addition of the crop residues or green manuring or even FYM has a very little effect on soil organic carbon in dryland condition. The data of long-term experimentation showed the improvement and maintenance of the soil organic carbon content in dryland agriculture as a result of judicious use of gliricidia green leaf manure and well decomposed FYM in combination with the inorganic fertilizers. Use of organic or inorganic plant nutrient sources alone was not helpful in significant build up of organic carbon in soils under dryland condition.

\section{Available Nitrogen}

The data (Table 2) on available nitrogen status of the experimental soil, indicated that significantly higher available nitrogen $\left(261.33 \mathrm{~kg} \mathrm{ha}^{-1}\right)$ was observed in treatment $\mathrm{T}_{6}(50 \%$ $\mathrm{N}$ ha ${ }^{-1}$ gliricidia $+50 \% \mathrm{~N}+100 \% \mathrm{P}_{2} \mathrm{O}_{5}+100 \% \mathrm{~K}_{2} \mathrm{O}$ ha $^{-1}$ fertilizers) which was on par (259.24 $\left.\mathrm{kg} \mathrm{ha}^{-1}\right)$ with application of $50 \% \mathrm{~N} \mathrm{ha}^{-1} \mathrm{FYM}+50 \% \mathrm{~N}+100 \% \mathrm{P}_{2} \mathrm{O}_{5}+100 \% \mathrm{~K}_{2} \mathrm{O}$ ha $^{-1}$ fertilizers $\left(\mathrm{T}_{7}\right)$ and treatment $\left(\mathrm{T}_{8}\right)$ application of $100 \% \mathrm{~N} \mathrm{ha}^{-}$ ${ }^{1}$ gliricidia $+100 \% \mathrm{P}_{2} \mathrm{O}_{5}+100 \% \mathrm{~K}_{2} \mathrm{O}$ ha $^{-1}$ fertilizers $(252.97$ $\left.\mathrm{kg} \mathrm{ha}^{-1}\right)$. It was also noted that $28.7 \%$ and $10.6 \%$ increase in available $\mathrm{N}$ content was recorded with application of $50 \% \mathrm{~N}$ ha $^{-1}$ gliricidia $+50 \% \mathrm{~N}+100 \% \mathrm{P}_{2} \mathrm{O}_{5}+100 \% \mathrm{~K}_{2} \mathrm{O}$ ha $^{-1}$ fertilizers $\left(\mathrm{T}_{6}\right)$ as compared to control $\left(\mathrm{T}_{1}\right)$ and $100 \%$ RDF $\left(\mathrm{T}_{2}\right)$, respectively. The lowest available nitrogen $(202.79 \mathrm{~kg}$ $\mathrm{ha}^{-1}$ ) was observed in absolute control $\left(\mathrm{T}_{1}\right)$.

The higher value of available $\mathrm{N}$ over the initial value might be due to nitrogen fixation by greengram crop. The favorable soil conditions under gliricidia/FYM addition might have helped in mineralization of soil $\mathrm{N}$ leading to build up of higher available N. Similar results were also reported by Shirale and Khating (2009) ${ }^{[12]}$, Deshmukh et al. (2011) ${ }^{[4]}$, Gabhane et al. (2013) ${ }^{[5]}$, Naik (2016) ${ }^{[7]}$ and Chandel et al. (2017) ${ }^{[3]}$.

\section{Available Phosphorus}

The data indicates that the treatments $\left(\mathrm{T}_{6} \& \mathrm{~T}_{7}\right)$ which received $50 \% \mathrm{~N}$ fertilizers $+100 \% \mathrm{P}_{2} \mathrm{O}_{5}+100 \% \mathrm{~K}_{2} \mathrm{O}$ ha $^{-1}$ 
fertilizers with $50 \% \mathrm{~N}$ either through gliricidia lopping or FYM recorded higher content of available phosphorus over all other treatments. The maximum $18.59 \mathrm{~kg} \mathrm{ha}^{-1}$ available phosphorus was recorded in treatment $50 \% \mathrm{~N} \mathrm{ha}^{-1}$ gliricidia + $50 \% \mathrm{~N}+100 \% \mathrm{P}_{2} \mathrm{O}_{5}+100 \% \mathrm{~K}_{2} \mathrm{O} \mathrm{ha}^{-1}$ fertilizers $\left(\mathrm{T}_{6}\right)$ and was on par $\left(17.25 \mathrm{~kg} \mathrm{ha}^{-1}\right)$ with treatment application of $50 \% \mathrm{~N} \mathrm{ha}$ ${ }^{1} \mathrm{FYM}+50 \% \mathrm{~N}+100 \% \mathrm{P}_{2} \mathrm{O}_{5}+100 \% \mathrm{~K}_{2} \mathrm{O}$ ha $^{-1}$ fertilizers $\left(\mathrm{T}_{7}\right)$.

It was also noted that $72.9 \%$ and $11 \%$ increase in available phosphorus content was recorded with application of $50 \% \mathrm{~N}$ $\mathrm{ha}^{-1}$ gliricidia $+50 \% \mathrm{~N}+100 \% \mathrm{P}_{2} \mathrm{O}_{5}+100 \% \mathrm{~K}_{2} \mathrm{O}$ ha $^{-1}$ fertilizers $\left(\mathrm{T}_{6}\right)$ as compared to control $\left(\mathrm{T}_{1}\right)$ and $100 \% \mathrm{RDF}$ $\left(\mathrm{T}_{2}\right)$, respectively. The lowest $10.75 \mathrm{~kg} \mathrm{ha}^{-1}$ available $\mathrm{P}$ was observed in control treatment.

The increase in available phosphorus status is due to use of gliricidia/FYM, being direct source of phosphorus and it might have also solubilized the native phosphorus in the soil through release of various organic acids which had chelating effect, that reduced phosphorus fixation. The higher values of available phosphorus in treatment $T_{6}$ and $T_{7}$ may be due to addition of phosphorus through FYM/ gliricidia in soil. Similar results were recorded by Vaiyapuri et al. (2008) ${ }^{[14]}$, Regar et al. (2009) [9], Shirale and Khating (2009) [12], Vidyavathi et al. (2011) ${ }^{[15]}$ and Naik (2016) ${ }^{[7]}$.

\section{Available Potassium}

The black soils developed from basalt have the major quantity of the mineral feldspar which is rich in $\mathrm{K}, \mathrm{Na}$ and $\mathrm{Ca}$, hence potash fertilizers are not recommended for the crops grown on black soils. The swelling and shrinkage property of black clayey soils trap the $\mathrm{K}$ ions in crystal lattice. The data on available potassium status of the experimental soil, indicated that significantly

Table 2: Effect of long term INM treatments on soil fertility

\begin{tabular}{|c|c|c|c|c|}
\hline \multirow{2}{*}{\multicolumn{2}{|c|}{ Treatments }} & \multicolumn{3}{|c|}{ Available Nutrients $\left(\mathrm{kg} \mathrm{ha}^{-1}\right)$} \\
\hline & & \multirow{2}{*}{$\begin{array}{c}\mathbf{N} \\
202.79\end{array}$} & \multirow{2}{*}{$\begin{array}{c}\mathbf{P} \\
10.75\end{array}$} & \multirow{2}{*}{$\begin{array}{c}\mathbf{K} \\
306.13\end{array}$} \\
\hline $\mathrm{T}_{1}$ & Control & & & \\
\hline $\mathrm{T}_{2}$ & $100 \%$ RDF & 236.25 & 16.73 & 339.73 \\
\hline $\mathrm{T}_{3}$ & $50 \%$ RDF & 225.79 & 13.81 & 324.80 \\
\hline $\mathrm{T}_{4}$ & $50 \% \mathrm{~N} \mathrm{ha}^{-1}$ gliricidia & 229.97 & 14.86 & 328.53 \\
\hline $\mathrm{T}_{5}$ & $50 \% \mathrm{~N} \mathrm{ha}^{-1} \mathrm{FYM}$ & 232.06 & 14.78 & 336.00 \\
\hline $\mathrm{T}_{6}$ & $50 \% \mathrm{~N}$ fertilizers $+50 \% \mathrm{~N}^{-1}$ haliricidia $+100 \% \mathrm{P}_{2} \mathrm{O}_{5}+100 \% \mathrm{~K}_{2} \mathrm{O}^{-1}$ fertilizers & 261.33 & 18.59 & 399.47 \\
\hline $\mathrm{T}_{7}$ & $50 \% \mathrm{~N}$ fertilizers $+50 \% \mathrm{~N} \mathrm{ha}^{-1} \mathrm{FYM}+100 \% \mathrm{P}_{2} \mathrm{O}_{5}+100 \% \mathrm{~K}_{2} \mathrm{O} \mathrm{ha}^{-1}$ fertilizers & 259.24 & 17.25 & 395.73 \\
\hline $\mathrm{T}_{8}$ & $100 \% \mathrm{~N} \mathrm{ha}^{-1}$ gliricidia $+100 \% \mathrm{P}_{2} \mathrm{O}_{5}+100 \% \mathrm{~K}_{2} \mathrm{O} \mathrm{ha}^{-1}$ fertilizers & 252.97 & 17.02 & 392.00 \\
\hline & $\mathrm{SE}(\mathrm{m}) \pm$ & 5.47 & 0.60 & 18.94 \\
\hline & $\mathrm{CD}$ at $5 \%$ & 16.27 & 1.79 & 56.27 \\
\hline & Initial(1987-88) & 214 & 12.97 & 316.8 \\
\hline
\end{tabular}

higher available potassium (399.47 $\left.\mathrm{kg} \mathrm{ha}^{-1}\right)$ was observed in treatment $\mathrm{T}_{6}\left(50 \% \mathrm{~N} \mathrm{ha}^{-1}\right.$ gliricidia $+50 \% \mathrm{~N}+100 \% \mathrm{P}_{2} \mathrm{O}_{5}+$ $100 \% \mathrm{~K}_{2} \mathrm{O} \mathrm{ha}^{-1}$ fertilizers), followed by treatment $\left(\mathrm{T}_{7}\right)$ application of $50 \% \mathrm{~N}+100 \% \mathrm{P}_{2} \mathrm{O}_{5}+100 \% \mathrm{~K}_{2} \mathrm{O}$ ha $^{-1}$ through Urea, SSP \& MOP in combination with $50 \% \mathrm{~N} \mathrm{ha}^{-1}$ through FYM (395.73 kg ha-1) and 100\% $\mathrm{N} \mathrm{ha}^{-1}$ gliricidia $+100 \%$ $\mathrm{P}_{2} \mathrm{O}_{5}+100 \% \mathrm{~K}_{2} \mathrm{O}$ ha $^{-1}$ fertilizers $\left(392.00 \mathrm{~kg} \mathrm{ha}^{-1}\right)$. It was also noted that $30.5 \%$ and $17.6 \%$ increase in available $\mathrm{K}$ content was recorded with application of $50 \% \mathrm{~N} \mathrm{ha}^{-1}$ gliricidia $+50 \%$ $\mathrm{N}+100 \% \mathrm{P}_{2} \mathrm{O}_{5}+100 \% \mathrm{~K}_{2} \mathrm{O}$ ha $^{-1}$ fertilizers $\left(\mathrm{T}_{6}\right)$ as compared to control $\left(\mathrm{T}_{1}\right)$ and $100 \% \mathrm{RDF}\left(\mathrm{T}_{2}\right)$, respectively. The lowest available potassium $\left(306.13 \mathrm{~kg} \mathrm{ha}^{-1}\right)$ was observed in absolute control $\left(\mathrm{T}_{1}\right)$.

In general, the treatments $\left(\mathrm{T}_{6} \& \mathrm{~T}_{7}\right)$ which received gliricidia lopping/FYM in combination with fertilizers showed better performance in respect of available potassium over all other treatments. Thus, the results indicate that to exploit the inherent potential available potash supplying capacity of black soil, application of the FYM/gliricidia in combination with the inorganic fertilizers is necessary.

Thus, from the data, it is revealed that, application $50 \% \mathrm{~N}+$ $100 \% \mathrm{P}_{2} \mathrm{O}_{5} \mathrm{ha}^{-1}+100 \% \mathrm{~K}_{2} \mathrm{O}$ ha $^{-1}$ through urea, SSP and MOP $+50 \% \mathrm{~N} \mathrm{ha}^{-1}$ through gliricidia/FYM resulted in build up of soil fertility. The build up of soil available $\mathrm{K}$ by the application of potassium through gliricidia green leaf manuring and FYM might be due to the fact that gliricidia leaves contains higher amount of $\mathrm{K}$ and it is deposited in the soil and due to applied $\mathrm{K}$ through gliricidia green leaf manure, the solubilizing action of certain organic acids produced during decomposition results in greater capacity to hold $\mathrm{K}$ in the available form. Similar results were observed by Shirale and Khating (2009) ${ }^{[12]}$, Wagh et al. (2016) ${ }^{[16]}$, Naik et al. $(2018)^{[8]}$ and Satpute et al. $(2019)^{[10]}$.

Nutrient balance: The data on nutrient (N, P \& K) balance as influenced by various treatments are presented in Table 3

Table 3: Effect of long term INM treatments on nutrient balance in cotton+ greengram intercropping system

\begin{tabular}{|c|c|c|c|c|c|c|}
\hline \multirow{2}{*}{ Treatment } & \multicolumn{3}{|c|}{ Nutrient status at the end $(2019-20)\left(\mathrm{kg} \mathrm{ha}^{-1}\right)$} & \multicolumn{3}{|c|}{ Net gain $(+) /$ Loss $(-)\left(\mathrm{kg} \mathrm{ha}^{-1}\right)$} \\
\hline & $\mathbf{N}$ & $\mathbf{P}$ & $\mathbf{K}$ & $\mathbf{N}$ & $\mathbf{P}$ & K \\
\hline $\mathrm{T}_{1}$ & 202.79 & 10.75 & 306.13 & -11.2 & -2.2 & -10.7 \\
\hline $\mathrm{T}_{2}$ & 236.25 & 16.73 & 339.73 & 22.2 & 3.8 & 22.9 \\
\hline $\mathrm{T}_{3}$ & 225.79 & 13.81 & 324.80 & 11.8 & 0.8 & 8.0 \\
\hline $\mathrm{T}_{4}$ & 229.97 & 14.86 & 328.53 & 16.0 & 1.9 & 11.7 \\
\hline $\mathrm{T}_{5}$ & 232.06 & 14.78 & 336.00 & 18.1 & 1.8 & 19.2 \\
\hline $\mathrm{T}_{6}$ & 261.33 & 18.59 & 399.47 & 47.3 & 5.6 & 82.7 \\
\hline $\mathrm{T}_{7}$ & 259.24 & 17.25 & 395.73 & 45.2 & 4.3 & 78.9 \\
\hline $\mathrm{T}_{8}$ & 252.97 & 17.02 & 392.00 & 39.0 & 4.1 & 75.2 \\
\hline Initial & 214 & 12.97 & 316.8 & - & - & - \\
\hline
\end{tabular}


The data in respect of nitrogen balance indicate the gain of nitrogen in all the treatments except control. However, the higher gain of nitrogen (47.3 $\left.\mathrm{kg} \mathrm{ha}^{-1}\right)$ was recorded with application of $50 \% \mathrm{~N} \mathrm{ha}^{-1}$ gliricidia $+50 \% \mathrm{~N}+100 \% \mathrm{P}_{2} \mathrm{O}_{5}+$ $100 \% \mathrm{~K}_{2} \mathrm{O} \mathrm{ha}{ }^{-1}$ fertilizers $\left(\mathrm{T}_{6}\right)$ followed by $45.2 \mathrm{~kg} \mathrm{ha}^{-1}$ with application of $50 \% \mathrm{~N} \mathrm{ha}^{-1} \mathrm{FYM}+50 \% \mathrm{~N}+100 \% \mathrm{P}_{2} \mathrm{O}_{5}+$ $100 \% \mathrm{~K}_{2} \mathrm{O} \mathrm{ha}{ }^{-1}$ fertilizers $\left(\mathrm{T}_{7}\right)$. The results revealed that, the combined use of nitrogen sources i.e. fertilizer and organic matter is essential for improvement in available $\mathrm{N}$ content of soil.

The data in respect of phosphorus balance indicate the gain of phosphorus in the treatments where gliricidia and FYM were used as organic sources in combination with inorganic fertilizers. However, the higher gain of phosphorus $(5.6 \mathrm{~kg}$ ha ${ }^{1}$ ) was recorded in treatment $T_{6}$ followed by $T_{7}\left(4.3 \mathrm{~kg} \mathrm{ha}^{-1}\right)$.

The data in respect of potassium balance indicate the gain of potassium in all the treatments except control. However higher gain of potassium $\left(82.7 \mathrm{~kg} \mathrm{ha}^{-1}\right)$ was recorded with application of $50 \% \mathrm{~N} \mathrm{ha}^{-1}$ gliricidia $+50 \% \mathrm{~N}+100 \% \mathrm{P}_{2} \mathrm{O}_{5}+$ $100 \% \mathrm{~K}_{2} \mathrm{O} \mathrm{ha}{ }^{-1}$ fertilizers $\left(\mathrm{T}_{6}\right)$ followed by $78.9 \mathrm{~kg} \mathrm{ha}^{-1}$ with application of $50 \% \mathrm{~N} \mathrm{ha}^{-1} \mathrm{FYM}+50 \% \mathrm{~N}+100 \% \mathrm{P}_{2} \mathrm{O}_{5}+$ $100 \% \mathrm{~K}_{2} \mathrm{O}$ ha $^{-1}$ fertilizers $\left(\mathrm{T}_{7}\right)$. The higher gain was noticed where gliricidia and FYM were used as organic sources in combination with inorganic fertilizers.

\section{Conclusion}

The integrated application of 50\% $\mathrm{N}$ through gliricidia / FYM+ 50\% $\mathrm{N}+100 \% \mathrm{P}_{2} \mathrm{O}_{5}+100 \% \mathrm{~K}_{2} \mathrm{O}$ ha $^{-1}$ through fertilizers resulted in improvement in soil fertility with higher nutrient balance in cotton + greengram (1:1) intercropping system in Vertisols under rainfed conditions.

\section{References}

1. Anonymous. ICAR AICRP (Cotton) Annual Report Coimbatore, Tamil Nadu, India 2019-20a.

2. Anonymous. http://krishi.maharashtra.gov.in, Department of Agriculture, Govt. of Maharashtra 2019-20b.

3. Chandel Ashwini, Gabhane VV, Nagdeve MB, Turkhede AB, Patode RS. Effect of INM on soil fertility, productivity and economics of cotton + greengram intercropping system in Vertisols. International Journal of Current Microbiology and Applied Sciences 2017;6(11):3738-3743.

4. Deshmukh SV, Kudtarkar US, Gaikwad SP, Patil KB. Yield and nutrient uptake of kharif $B t$ cotton as influenced by conjoint use of FYM and chemical fertilizer. Advance Research Journal of Crop Improvement 2011;2(1):115-120.

5. Gabhane Vijay, Nagdeve Mahendra, Ganvir Mahipal. Effect of long term integrated nutrient management on sustaining crop productivity and soil fertility under cotton and greengram intercropping in Vertisols under semi-arid agro-ecosystem of Maharashtra, India. Acta biologica indica 2013;2(1):284-291.

6. Meena RS, Yadav RS, Meena H, Kumar S, Meena YK, Singh A. Towards the current need to enhance legume productivity and soil sustainability worldwide: A book review. Journal of Cleaner Production 2015;104:513-515.

7. Naik Rajesh K. Soil fertility and cotton productivity as influenced by potash management through gliricidia green leaf manuring in Vertisols. M.Sc. Thesis (Unpub.) Dr. PDKV, Akola 2016.

8. Naik Rajesh K, Gabhane VV, Chandel Ashwini, Nagdeve MB. Soil fertility and cotton productivity as influenced by potash management through gliricidia green leaf manuring in Vertisols. Special issue ICAAASTSD-2018. Multilogic in Science (VII), 207-209.

9. Regar PL, Rao SS, Vyas SP. Crop residue management for sustainable production of Indian mustard (Brassica juncea) in arid and semi-arid region. Indian Journal of Soil Conservation 2009;37(2):118-122.

10. Satpute Usha V, Gabhane VV, Jawale SA, Jadhao VH. Impact of potash application through glyricidia green leaf manuring on yield and nutrient uptake by cotton in Vertisols. Journal of Pharmacognosy and Phytochemistry 2019;8(3):4111-4114.

11. Sharma KL, Kusuma Grace J, Mishra PK, Venkateswarlu B, Nagdeve MB, Gabhane VV et al. Effect of soil and nutrient management treatments on soil quality indices under cotton-based production system in rainfed semiarid tropical Vertisol. Communications in Soil Science and Plant Analysis 2011;42(11):1298-1315.

12. Shirale ST, Khating LE. Effect of organic and inorganic nutrients on yield, nutrient uptake and balance in different cropping systems in Vertisol. Annals of Plant Physiology 2009;23(1):83- 85.

13. Tamboli BD, Bagwan IR, Pawar AB, Bhakare BD, Shelke SR, Kadam JR et al. Integrated nutrient management for sustaining rabi sorghum yield, economics and soil fertility on Inceptisol under dryland condition. Indian Journal of Dryland Agricultural Research and Development 2013;28(1):70-73.

14. Vaiyapuri K, Amanullah MM, Somasundaram E, Sathyamoorthi K, Pazhaznivelan S. Post harvest soil chemical and physical properties and cotton yield as influenced by intercropping unconventional green manuring in cotton. Green Farming 2008;2(1):47.

15. Vidyavathi GS, Babalad Dasog B, Hebsur NS, Gali SK, Patil SG, Alagawadi AR. Influence of nutrient management practices on crop response and economics in different cropping systems in a Vertisol. Karnataka Journal of Agricultural Science 2011;24(4):455-460.

16. Wagh NS, Katkar RN, Kharche VK. Effect of tillage and nutrient management on seed cotton yield, yield contributing characters and total uptake by cotton. An Asian Journal of Soil Science 2016;11(2):277-285. 